\title{
The Ability of Writing Fairy Tales through the Implementation of Audio Visual Learning Media
}

\author{
Winarti $^{1}$, Mutia Febriyana ${ }^{2}$, Enny Rahayu ${ }^{3}$ \\ ${ }_{1,2,3}$ Universitas Muhammadiyah Sumatera Utara, Indonesia \\ winarti@umsu.ac.id,mutiafebriyana@umsu.ac.id,enny_wisman@yahoo.co.id
}

\begin{abstract}
The purpose of this study was to determine the application of audiovisual learning media to the ability to write fairy tales by fifth semester students of the Indonesian Language Education study program at FKIP UMSU for the 2019-2020 academic year. The sample in this study was set randomly so that the chosen class $V A$ morning as the experimental class and class $V B$ morning as the control class. The sample consisted of 46 students consisting of 30 people in the experimental class and 16 people in the control class. The research location is in the Indonesian Language Education Study Program FKIP UMSU on Jalan Mukhtar Basri No. 3 Medan. The results in this study are that there is a significant influence of audiovisual learning media on the ability to write fairy tales by fifth semester students of the Indonesian Language Study Program FKIP UMSU in the academic year 2019-2020. The method used in this study is an experimental method, while the instrument used is an essay test in the form of writing a fairy tale.
\end{abstract}

Keywords

audiovisual learning media; nonaudiovisual; fairy tale witing

\section{Introduction}

Education that is carried out from time to time is always changing in accordance with the times. Therefore, teachers as learning managers are required to be more creative and innovative in order to make learning outcomes more optimal (Simorangkir and Sembiring, 2018). According to Ghofur et al (2019) in the digital era, learning of writing is not enough to be taught manually but must use information and communication technology as an instrument for storing data and publishing various information in order can be used by international community.

The curiosity of researchers on fairy tales is quite large. Students are equipped with different imagination. There are those who without thinking can quickly produce a fairy tale whether the results of the fairy tale are interesting or not, some have long thought and takes a lot of time cannot produce a fairy tale satisfactorily.

In fairy tale material, there are students who like to listen to fairy tales but once asked to write fairytales lose their enthusiasm, there are students who seem distrustful of fairy tales because fairy tales for them are unthinkable hoaxes, some are not at all interested in fairy tales.

Phenomena such as this become the background for researchers wanting to continue research on fairy tales, but by using different strategies or media. If in the past year the researcher used the power of two learning strategy or wrote a fairy tale in pairs alternately writing it with friends, but this time with learning media namely audiovisual.

Audiovisual learning media is a medium that utilizes images and sound as the medium. Students will be asked to listen and see a fairy tale video then try to write a fairy tale after seeing the video. 
Writing fairy tales is one of the activities of literature. Literature is a personal expression of human beings in the form of experiences, thoughts, feelings, ideas, enthusiasm, beliefs in a form of concrete images that evoke enchantment with the tools of language. One that arouses that charm is children's literature. Huck in Mursini (2016: 16) revealed that whoever writes children's literature (including fairy tales) need not be questioned as long as the portrayal is emphasized on the lives of children who have a meaningful value to them.

Based on the description above, researchers are interested in conducting research under the title "The Application of Audiovisual Learning Media to the Ability to Write Storytelling by Semester V Students of the Indonesian Language Education Study Program FKIP UMSU T.A. 2019-2020.

\subsection{Formulation of the Problem}

The formulation of the problem in this study is how the results of the application of audiovisual and nonaudiovisual learning media to the ability to write fairy tales by fifth semester students of the Indonesian Language Study Program FKIP UMSU?

\subsection{Research Purposes}

The purpose of this study was to determine the results of the application of audiovisual and nonaudiovisual learning media to the ability to write fairy tales by fifth semester students of the Indonesian Language Study Program FKIP UMSU.

\subsection{Research Benefits}

It is hoped that this research will be useful in the following matters:

1. This research is expected to be an input for lecturers of Indonesian Children's Literature Studies to teach fairy writing material to students in accordance with audiovisual learning media.

2. As input for students to be able to improve and develop literary works, especially in learning to write stories when they have become teachers.

3. As a reference material that is very useful in further research.

\section{Research Methods}

According to Sugiyono (2010: 2), research methods are basically scientific ways to obtain data with specific purposes and uses. The purpose of this study was to determine the results of the application of audiovisual learning media to the ability to write fairy tales. Whether or not a study was successful, was determined by the method used.

In accordance with the problem and research objectives, the experimental method is used. According to Sugiyono (2010: 72), the experimental research method can be interpreted as a research method used to look for the effects of certain other treatments under controlled conditions. 


\section{Results and Discussion}

The researcher used a fairytale writing ability test in this study. After carrying out the distribution of tests to 46 students, it can be known the value of the ability to write fairy tales using audiovisual and nonaudiovisual learning media by fifth semester students of the Indonesian Language Study Program FKIP UMSU in the academic year 2019-2020. Furthermore, the test results are processed into several stages. Based on the results of tests that have been checked, the values obtained are presented in the form of the following table. This test was carried out in February 2020 Building B FKIP UMSU before being declared lockdown by the government due to the covid 19 pandemic (corona virus).

Table 1. Raw Score Table Ability to Write Fairy Tales in Experiment Class (V-A)

\begin{tabular}{|c|c|c|c|c|c|}
\hline No. & Name & Fantasy & Characterization & Mandate & Total \\
\hline 1 & Astrika Irawan Nst. & 3 & 3 & 3 & 9 \\
\hline 2 & Ayu Ratna Utary & 3 & 2 & 2 & 7 \\
\hline 3 & Wiwik Artika Sari & 3 & 3 & 3 & 9 \\
\hline 4 & Dian Aulia M. & 3 & 3 & 3 & 9 \\
\hline 5 & Dien Sukma A. & 3 & 2 & 2 & 7 \\
\hline 6 & Ayu Mayang Sari & 3 & 2 & 2 & 7 \\
\hline 7 & Dewi Syafitri Siregar & 2 & 2 & 3 & 7 \\
\hline 8 & Eliyani & 2 & 2 & 2 & 6 \\
\hline 9 & Ernala Sembiring & 3 & 2 & 2 & 7 \\
\hline 10 & Euis Widia Nabillah & 3 & 2 & 2 & 7 \\
\hline 11 & Inayah Nurhuda & 3 & 3 & 2 & 8 \\
\hline 12 & Indah Retno Sari & 3 & 3 & 3 & 9 \\
\hline 13 & Miftah Maulidya & 3 & 3 & 2 & 8 \\
\hline 14 & Nova Nana & 3 & 3 & 3 & 9 \\
\hline 15 & Puspika Nadia & 2 & 2 & 2 & 6 \\
\hline 16 & Sari Ladola & 1 & 1 & 1 & 3 \\
\hline 17 & Siti Kholifah & 2 & 2 & 2 & 6 \\
\hline 18 & Sri Deva & 2 & 2 & 2 & 6 \\
\hline 19 & Surya Fia M. & 3 & 3 & 2 & 8 \\
\hline 20 & Ulfa Sahfitri & 3 & 3 & 2 & 8 \\
\hline 21 & Winda Silvya & 3 & 3 & 2 & 8 \\
\hline 22 & Farida Nst. & 2 & 2 & 2 & 6 \\
\hline 23 & Latifah Anum & 3 & 3 & 2 & 8 \\
\hline 24 & Nurhaliza S. & 3 & 2 & 2 & 7 \\
\hline 25 & Nurlita Aulia & 2 & 2 & 2 & 6 \\
\hline 26 & Rira Efrida & 3 & 2 & 2 & 7 \\
\hline 27 & Shella Dwinta & 2 & 2 & 2 & 6 \\
\hline 28 & Sri Etika & 3 & 2 & 2 & 7 \\
\hline 29 & Tuty Fatmawati S. & 3 & 3 & 3 & 9 \\
\hline \multirow[t]{2}{*}{30} & Widya Safitri & 3 & 3 & 2 & 8 \\
\hline & Total & & & & 218 \\
\hline
\end{tabular}


Table 2. Raw Score Table Ability to Write Fairy Tales in the Control Class (V-B)

\begin{tabular}{|c|l|c|c|c|c|}
\hline No. & \multicolumn{1}{|c|}{ Name } & Fantasy & Characterization & Mandate & Total \\
\hline 1 & Adira Oktaviani & 3 & 3 & 3 & 9 \\
\hline 2 & Anggita Desiana & 3 & 2 & 2 & 7 \\
\hline 3 & Dessi Andriyanti & 2 & 2 & 2 & 6 \\
\hline 4 & Dian Febrita K. & 2 & 2 & 2 & 6 \\
\hline 5 & Fitra Mawardah S. & 3 & 2 & 2 & 7 \\
\hline 6 & Hafizah Roma Putra & 3 & 3 & 3 & 9 \\
\hline 7 & Herdianti Rukmana & 3 & 2 & 3 & 8 \\
\hline 8 & Lidia Indah Sari & 2 & 2 & 2 & 6 \\
\hline 9 & Mia Aulya & 2 & 2 & 2 & 6 \\
\hline 10 & Raushan Fikri & 3 & 2 & 2 & 7 \\
\hline 11 & Ria Novi S. & 3 & 2 & 2 & 7 \\
\hline 12 & Rizka Alany P. & 2 & 2 & 2 & 6 \\
\hline 13 & Sajri Nauli & 2 & 2 & 1 & 6 \\
\hline 14 & Tika Yonanda H. & 2 & 2 & 2 & 6 \\
\hline 15 & Vinky Rohana & 1 & 1 & & $\mathbf{1 0 5}$ \\
\hline 16 & Winda Aprisnadia & 2 & 2 & & \\
\hline & \multicolumn{1}{|c|}{ Total } & & & & 2 \\
\hline
\end{tabular}

Before calculating the average value of students, the student's final grade is calculated first so that the average value and standard deviation can be calculated. To calculate the mean and standard deviation of the experimental class, a work table is needed to calculate the average and standard deviation as follows.

Table 3. Work Table Calculates Final Score, Average Value, and Standard Deviation of Experiment Classes

\begin{tabular}{|c|l|c|c|l|}
\hline No. & \multicolumn{1}{|c|}{ Name } & Raw score & Final score $(\mathbf{X})$ & \multicolumn{1}{c|}{$\mathbf{X}^{\mathbf{2}}$} \\
\hline 1 & Astrika Irawan Nst. & 9 & 100 & 10.000 \\
\hline 2 & Ayu Ratna Utary & 7 & 77.77 & 6048.17 \\
\hline 3 & Wiwik Artika Sari & 9 & 100 & 10.000 \\
\hline 4 & Dian Aulia M. & 9 & 100 & 10.000 \\
\hline 5 & Dien Sukma A. & 7 & 77.77 & 6048.17 \\
\hline 6 & Ayu Mayang Sari & 7 & 77.77 & 6048.17 \\
\hline 7 & Dewi Syafitri Siregar & 7 & 77.77 & 6048.17 \\
\hline 8 & Eliyani & 6 & 66.66 & 4443.55 \\
\hline 9 & Ernala Sembiring & 7 & 77.77 & 6048.17 \\
\hline 10 & Euis Widia Nabillah & 7 & 77.77 & 6048.17 \\
\hline 11 & Inayah Nurhuda & 8 & 88.88 & 7899.65 \\
\hline 12 & Indah Retno Sari & 8 & 100 & 10.000 \\
\hline 13 & Miftah Maulidya & 9 & 88.88 & 7899.65 \\
\hline 14 & Nova Nana & 6 & 100 & 10.000 \\
\hline 15 & Puspika Nadia & 3 & 66.66 & 4443.55 \\
\hline 16 & Sari Ladola & 6 & 33.33 & 1110.88 \\
\hline 17 & Siti Kholifah & 6 & 66.66 & 4443.55 \\
\hline 18 & Sri Deva & 8 & 66.66 & 4443.55 \\
\hline 19 & Surya Fia M. & 8 & 88.88 & 7899.65 \\
\hline 20 & Ulfa Sahfitri & 88.88 & 7899.65 \\
\hline
\end{tabular}




\begin{tabular}{|l|l|c|c|l|}
\hline 21 & Winda Silvya & 8 & 88.88 & 7899.65 \\
\hline 22 & Farida Nst. & 6 & 66.66 & 4443.55 \\
\hline 23 & Latifah Anum & 8 & 88.88 & 7899.65 \\
\hline 24 & Nurhaliza S. & 7 & 77.77 & 6048.17 \\
\hline 25 & Nurlita Aulia & 6 & 66.66 & 4443.55 \\
\hline 26 & Rira Efrida & 7 & 77.77 & 6048.17 \\
\hline 27 & Shella Dwinta & 6 & 66.66 & 4443.55 \\
\hline 28 & Sri Etika & 7 & 77.77 & 6048.17 \\
\hline 29 & Tuty Fatmawati S. & 9 & 100 & 10.000 \\
\hline 30 & Widya Safitri & 8 & 88.88 & 7899.65 \\
\hline & Total & $\mathbf{2 1 8}$ & $\mathbf{2 4 2 2 . 0 4}$ & $\mathbf{2 0 1 . 9 4 6 . 8 1}$ \\
\hline
\end{tabular}

Based on the table above it can be seen that:

$\mathrm{N}_{1}=30$

$$
\sum x_{1}=2422.04 ; \sum x_{l}^{2}=201.946 .81
$$

So:

$$
\bar{x}_{1}=\frac{\sum x_{1}}{n_{1}}=\frac{2422.04}{30}=80.73
$$

Based on the above calculation, the mean or mean value of 80.73 is obtained. The next step is to calculate the standard deviation of the experimental class using the following formula

$$
\begin{array}{r}
S D_{1}=\sqrt{\frac{n_{1} \sum x_{1}{ }^{2}-\left(\sum x_{1}\right)^{2}}{n_{1}\left(n_{1}-1\right)}} \\
=\sqrt{\frac{30(201.946 .81)-(2422.04)^{2}}{30(30-1)}} \\
=\sqrt{\frac{6.058 .404 .3-5.866 .277 .7}{870}} \\
S D_{1}=\sqrt{\frac{192.126,6}{870}}=\sqrt{220.83}=14.86
\end{array}
$$

Two calculations above can be seen that the average value of students is 80.73 with a standard deviation of 14.86. By using the student's final grade guidelines, then the student grade categories can be arranged as in the following table. 
Table 4. Student Grade Categories Experiment Class

$\begin{array}{ll}\text { No. } & \text { Value Range } \\ \text { 1. } & 80-100 \\ \text { 2. } & 66-79 \\ \text { 3. } & 56-65 \\ \text { 4. } & 40-55 \\ \text { 5. } & <39\end{array}$

Total

Average value

\section{Category}

Very good

Good

Enough

Less

Failed
Total

13

16

-

1

30

80.73
Percentage

$43.33 \%$

$53.33 \%$

$3.33 \%$

$99.99 \%$

Very good

Before calculating the average value, the student's final grade is calculated first so that the average value and standard deviation can be calculated. To calculate the mean (mean) and standard deviation of the control class, a work table is needed to calculate the average and standard deviation as follows.

Table 5. Work Table Calculates Final Score, Average Value, and Control Class Deviation Standards

\begin{tabular}{|c|c|c|l|l|}
\hline No & Name & $\begin{array}{c}\text { Raw } \\
\text { Score }\end{array}$ & $\begin{array}{c}\text { Final Score } \\
(\mathbf{x})\end{array}$ & $\mathbf{X}^{\mathbf{2}}$ \\
\hline 1 & Adira Oktaviani & 9 & 100 & 10.000 \\
\hline 2 & Anggita Desiana & 7 & 77.77 & 6048.17 \\
\hline 3 & Dessi Andriyanti & 6 & 66.66 & 4443.55 \\
\hline 4 & Dian Febrita K. & 6 & 66.66 & 4443.55 \\
\hline 5 & Fitra Mawardah S. & 7 & 77.77 & 6048.17 \\
\hline 6 & Hafizah Roma Putra & 9 & 100 & 10.000 \\
\hline 7 & Herdianti Rukmana & 8 & 88.88 & 7899.65 \\
\hline 8 & Lidia Indah Sari & 6 & 66.66 & 4443.55 \\
\hline 9 & Mia Aulya & 6 & 66.66 & 4443.55 \\
\hline 10 & Raushan Fikri & 7 & 77.77 & 6048.17 \\
\hline 11 & Ria Novi S. & 7 & 77.77 & 6048.17 \\
\hline 12 & Rizka Alany P. & 6 & 66.66 & 4443.55 \\
\hline 13 & Sajri Nauli & 6 & 66.66 & 4443.55 \\
\hline 14 & Tika Yonanda H. & 6 & 66.66 & 4443.55 \\
\hline 15 & Vinky Rohana & 3 & 33.33 & 1110.88 \\
\hline 16 & Winda Aprisnadia & 6 & 66.66 & 4443.55 \\
\hline & Total & $\mathbf{1 0 5}$ & $\mathbf{1 1 6 6 . 5 7}$ & $\mathbf{8 8 . 7 5 1 . 6 1}$ \\
\hline
\end{tabular}

Based on the table above it can be seen that:

$\mathrm{N}_{2}=16$

$$
\sum x_{2}=1.166 .57 ; \sum x_{2}{ }^{2}=88.751 .61
$$

So

$$
\bar{x}_{2}=\frac{\sum x_{2}}{n_{2}}=\frac{1.166 .57}{16}=72.91
$$


Based on the above calculation, the mean or mean value of 72.91 is obtained. The next step is to calculate the standard deviation of the control class, using the following formula.

$$
\begin{aligned}
S D_{2} & =\sqrt{\frac{n_{2} \sum x_{2}{ }^{2}-\left(\sum x_{2}\right)^{2}}{n_{2}\left(n_{2}-1\right)}} \\
& =\sqrt{\frac{16(88.751 .61)-(1166.57)^{2}}{16(16-1)}} \\
& =\sqrt{\frac{1.420 .025,76-1.360 .885,56}{240}} \\
S D_{2} & =\sqrt{\frac{59.140,2}{240}}=\sqrt{246,41}=15.69
\end{aligned}
$$

Based on the two calculations above, it can be seen that the average student score is 72.91 with a standard deviation of 15.69 .

Table 6. Control Class Student Value Categories

\begin{tabular}{lllcc} 
No. & Value Range & Category & Total & Percentage \\
1. & $80-100$ & Very good & 3 & $18.75 \%$ \\
2. & $66-79$ & Good & 12 & $75 \%$ \\
3. & $56-65$ & Enough & - & - \\
4. & $40-55$ & Less & - & - \\
5. & $<39$ & Failed & 1 & $6.25 \%$ \\
\multicolumn{5}{c}{ Total } \\
Averange Value & $\mathbf{1 6}$ & $\mathbf{1 0 0} \%$ \\
good
\end{tabular}

Based on the calculation of the average value and standard deviation of each experimental and control class, it can be concluded that the results of this study have a tendency towards the research variables. This research variable aims to determine the application of audiovisual and nonaudiovisual learning media to the ability to write fairy tales by fifth semester students of the Indonesian Language Study Program FKIP UMSU in the academic year 2019-2020. This can be seen from the magnitude of the average value obtained in the experimental class when compared with the control class that is $(80.73>72.91)$ so it can be concluded in outline that there is a successful implementation of audiovisual learning media on the ability to write fairytale writing by students.

This is seen based on calculations known the ability to write fairy tales taught using audiovisual learning media is in the very good category with an average value of 80.73 , while writing fairy tales taught using nonaudiovisual learning media has an average grade of 72.91 with good categories. 


\section{Conclusion}

From the results of the research that has been done, it can be concluded that there is a success in the audiovisual learning media for the ability to write fairy tales by 80.73 in the excellent category, while the success of the learning media by using nonaudiovisual is in the good category at an average value of 72.91 .

Suggestions that can be raised from the results of this study are:

1. Based on the research conducted, it can be suggested that the use of audiovisual learning media can be recommended in the teaching and learning process at universities, especially in the Indonesian language and literature education study program in the Indonesian Children's Literature Study course which discusses fairy tales.

2. Giving assignments using audiovisual learning media can be an additional learning medium for lecturers to improve learning outcomes and student motivation in learning languages and literature.

3. As input for other researchers who want to conduct research with the same focus on the ability of students to write stories.

\section{Acknowledgements}

Thank you so much for committee International Seminar on Language, Literature, and Education (ISELL-ED) 2020. I hope my paper can acceptable this moment. Thank you so much for LPPM UMSU, my department and my students.

\section{References}

Arikunto, Suharsami. 2013. Research Procedure A Practical Approach. Jakarta: Rineka Cipta. Ghofur, A., et al. (2019). Teaching Writing and Twenty First Century Skills Using Guided Autonomous Learning Designs. Budapest International Research and Critics InstituteJournal (BIRCI-Journal). P. 495-505.

Mursini. 2016. Appreciation and Learning of Children's Literature. Citapustaka Media Pioneer: Bandung.

Nurgiyantoro, Burhan. 2017. Children's Literature Introduction to Understanding the Children's World. Gadjah Mada University: Yogyakarta.

Simorangkir, F.M.A., and Sembiring, R.K.B. (2018). Effectiveness of Helped Mathematical Learning Media of Lectora Inspire on The Number Sense Ability of Fifth Grade Students of Elementary School in Substrate Materials. Budapest International Research and Critics Institute-Journal (BIRCI-Journal). P. 352-358.

Sugiyono 2010. Educational Research Methods Quantitative, Qualitative, and R\&D Approaches Bandung: Alfabeta.

Sembodo, Puguh Ario, 2015. Utilization of Audio Visual Media in Learning Music in SMP 5 Batang: Analysis of Process and Learning Outcomes. Essay. Semarang State University.

Wati, Ega Rima. 2016. Variety of Learning Media. Jakarta: Pena words

Winarti 2018. The Effect of The Power of Two Learning Strategy on the Ability to Write Storytelling by Semester V Students of the Indonesian Language and Literature Education Study Program FKIP UMSU T.A. 2018-2019. Medan: UMSU 